\title{
The social history of Canada
}

\author{
MICHAEL BLISS, EDITOR
}


A STUDY OF WORK AND PAY IN THE

CAMPS OF CANADA 1903-1914 


\section{The bunkhouse man}

EDMUND W. BRADWIN

WITH AN INTRODUCTION BY JEAN BURNET

UNIVERSITY OF TORONTO PRESS 
(c) University of Toronto Press 1972

Toronto and Buffalo

All rights reserved

ISBN (casebound) 0-8020-1848-3

ISBN (paperback) 0-8020-6135-4

Microfiche ISBN 0-8020-0166-1

LC 79-163834

Printed in the United States of America 